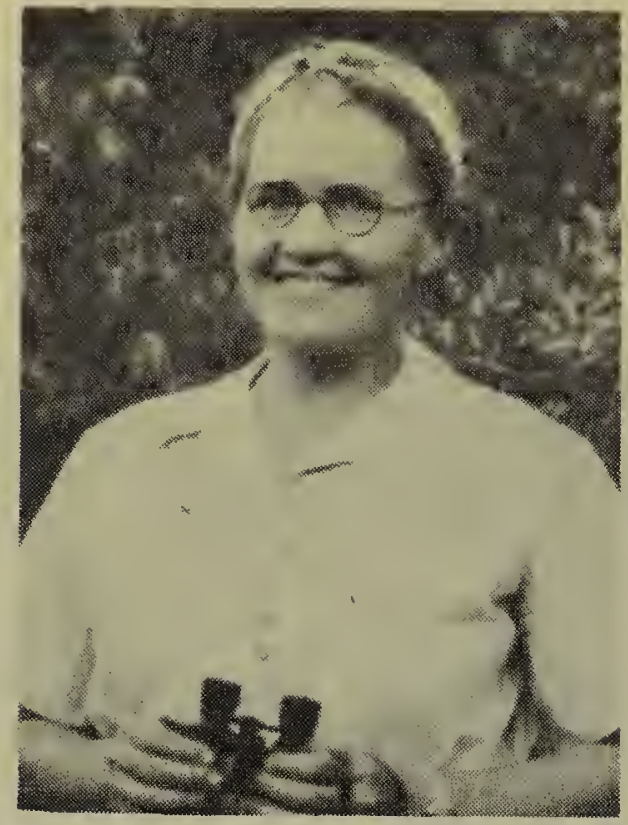

There is a surprising amount of nature lore to be picked up while cruising slowly over the many side roads leading out of Regina. Such evenings with friends have become delightful memories as the season closes.

The tremendous amount of water standing in the low places for so many weeks attracted numbers of shore and water birds. Often they were so close that we could watch them from the car windows going about their own affairs, but let one of us step onto the road and they were away in a flash of wings.

After many years of doing both, I feel it is much more rewarding to watch birds wherever they are seen than to tear madly over the country merely jotting down each species in an effort to secure the longest list possible.

At one time there were willets taking a bath with every evidence of intense pleasure. Others had gone mad, tearing about in circles evidently in pursuit of some elusive food Merely looking at black-bellied and golden plover sent a thrill along the spine when trying to visualize the country over which they had traveled. Just returning form Patagonia, they were headed far north, but stopped for a dip in our sloughs.

Ducks in spring with the evening light full upon them showed colors not noticed otherwise. They might be a pair of pintails that had taken over a pothole, or a number of ruddy ducks dashing up and down a water lane in their full regalia. There was never a dull moment.

One byway brought us to several

\section{Along The Byways}

\author{
By Elizabeth B. Flock
}

upl and plover on the ground, alighting with upstretched wings on fence posts, or flying about. Another led to the discovery of a meadowlark's nest in an open stubble field rather than among grasses as we find them usually .

Yet another brought us to a slough where four gorgeous avocets voiced disapproval of our presence. They put on wild displays of broken wings and legs even more convincing than those of killdeer. A young bird was discovered stretched perfectly flat on the ground and absolutely motionless where is remained as long as were in sight.

At times Hungarian partridge and priarie sharp-tailed grouse whirred away or walked stealthily seeking cover. When a prairie sharp-tail remained in the road, we stopped to watch Suddenly, it went into a dance all alone. A yellow band of feathers showed above each eye as the head was lowered. Purple air sacs on both sides of the neck were inflated. With stiffly spread wings and feet stamping in quick short steps, it danced in a semi-circle to a certain point where it whirled as if pulled by a string to retrace its step only to repeat the performance. When the bird disappeared finally behind a clump of willows, one of us stepped out of the car to investigate and instantly two females flew up from the grass to join the dancer in a hasty retreat.

One evening driving across Wascana valley and along the rim we counted twenty deer from the Old Crossing to the second bridge beyond. Some were close to the road, other were specks on the valley floor that came into focus when viewed through our glasses. Was it just good luck or have deer increased lately?

From time to time skunks have formed part of the evening picture. We watched one in a great hurry gallop over a plowed field, cross the road behind us and disappear into a tangle of bushes without appearing to notice us at all. None of us had the temerity to find out whether the home den was there or not, Another, a half-grown skunk, was so engrossed in catching 
located a cardboard box and placing the bird inside began to look about for some string to tie it shut. Seeing none, I decided to turn the box upside down. In doing so the bottom fell out and only narrowly did I escape getting struck in the eye by its sharp beak before recapturing it. Just then the farmer returned home and after showing him the bird, remarked, "You did well to get that fellow, must be the one that's getting my chickens". Swallowing hard, I explained that this was a Heron, not a Hawk. Arriving back in town'I dropped the bird, still in the box, at the office. Returning a few moments later, I was surprised to see every available article, including a chair, atop the box. It seems that a Bittern, more feathers than flesh, can escape through any opening that will allow the neck and one leg to be thrust through. The bird was released wearing a band at a suitable slough.

From my kitchen window I have a string running to an ordinary droptrap, 3 feet by 4 feet and 7 inches deep. This was one of my first traps. Having been used for several years, it caught over 2500 birds, it lacked a few repairs. Accidently, one day during my absence, it was tripped and remained so until my return that evening, My wife questioned me then, as to why 1 had left two birds in it. I said I hadn't. Then she explained she had released them. Examing the trap I found two small birds still in it. Being more puzzled, I noticed a small hole near the center of the trap, barely an inch in diameter and directly over the edge of the pan of water supplied from a water drip pail above. Knowing the birds had entered the trap through the small hole to get the water, I enlarged the hole to two inches square. From August lst to August 28th, this trap had taken nearly 400 Warblers, all having entered through this small hole. Nearly 300 of these Tennessee Warblers. The remainder being made up of the following species; Black \& White, Nashville, Capemay, Myrtle, Chestnut-sided, Bay-breasted, Palm. Mourning, and Redstarts. Incidently the nearly 300 Tennessees banded during this period are more than the average banded yearly by all banders together in North America. All this by a trap accidently tripped, and a small hole.

\section{Blue Hurons - (continued from page 6)}

The young are comical looking with their long legs and big bills. When angered, they look quite fierce, stretching long necks and raising the feathers on top of their heads. till it stands straight up. They don't hesitate to strike at your either and are quite capable of giving you a nasty peck.

When we left the trees that harboured the colony we came out on a beautiful flat and there stood at least fifty Blue Herons -- a sight that is worth travelling a long distance to behold.

Alone the Byways -

\section{(continued from page 20)}

grasshoppers, it almost stepped in front of the car, but swerved in time. There was a hasty retreat to the wheat field.

In the spring we noticed a number of jack rabbits walking rather than hopping about in the fields, It was an action we hadnever seen before. They seemed to be searching carefully for something as each would stop trom time to time and then proceed. When mentioning this to a friend later, he spoke of a rumor that at this time of year the males go on such walks in search of young rabbits to destroy them. Does anyone have further information on this theory?
Sunsets along these by ways were brilliant or dull according to the cloud formations. They were al ways something to watch with an uninterrupted view as we came back to town. The speedy passing of the weeks was cause for lamentation that all too soon such rides would be over until another year.

Pretty But Somewhat Sinelly (continued from page 14)

istic smell remained. Spider-flower belongs to the Capparidaceae or Caper fanily, in which family is the Caper used to make sauce for mutton. Incidentally, when I was a youngster we made our caper sauce from Nasturtium seeds and used their leaves in sandwiches. 